\title{
Chapter 9 \\ Comment: The Current State of Nonhuman Animal Agency
}

\author{
Joost Leuven
}

Daily at schools all over the world, human children rebel against their teachers. When they are forced to make assignments, they don't want to do, children often resist and try to challenge authority. This shows us that agency, the ability to make choices regarding their own lives, matters to them, at least to a certain extent. Good teachers try to accommodate the students' desire for agency by creating lessons and assignments in which there is room for students to make personal choices, like giving them the freedom to decide the specific topic for an essay or classroom presentation. Children don't lose this desire for agency once they grow up though and the desire for agency and the tendency to rebel against attempts to take that agency away, can be seen in human adults as well.

Human beings are not the only ones actively rebelling when their agency is curtailed. As we enter the geological era that some have fittingly named the Anthropocene (due to the increasing impact of human activity on ecosystems and geology), the examples of nonhuman animals trying to rebel against the increasing impediment of their agency also seem to become more numerous and frequent. We can see nonhuman animal rebellion in small and relatively harmless situations, like companion animals who refuse to be disciplined to use the litter box, but also under more serious circumstances, like livestock animals refusing to fall in line when entering a slaughterhouse (Palmer 2001). It is difficult to overstate the extent to which human beings nowadays control the lives of nonhuman animals. For the ones we keep in captivity, we control their movement, when and what they eat and even who they mate with, while the ones still living in the wild have to face the consequences of climate change, deforestation and the destruction of natural habitats in general. The existence of cases of rebellion forces us to consider the moral importance of agency in the lives of nonhuman animals.

\section{J. Leuven ( $\varangle)$}

The Hague, The Netherlands 
Especially in an era in which the overall relationship of humans with nonhuman animals is one of near total domination of human beings over nonhuman animal lives, it is necessary that moral philosophers look critically at the topic of self-realization in nonhuman animals. By reflecting on the attempts by the authors in this section of the book to do just that, this comment aims to make sense of nonhuman animal agency in the Anthropocene.

\subsection{Changing Perspectives Within Animal Ethics}

Traditionally the academic debate on animal ethics has focused predominantly on the question of whether nonhuman animal interests matter and how these interests should be taken into account. Authors such as Tom Regan (1983), Peter Singer (1975) and David Degrazia (1996) have contributed importantly to this debate, making cases against speciesism and in favor of animal rights and welfare. However, in recent years the debate has moved towards more complex questions and authors have now begun to challenge the idea that nonhuman animals are simply passive recipients of rights or care and argue that they are much more than that. Instead they should be seen as actors in a social (Gruen 2015), political (Donaldson and Kymlicka 2011) or moral (Monsó et al. 2018) sense. In their chapter, 'Taking Animal Perspectives into Account in Animal Ethics', Eva Meijer and Bernice Bovenkerk explore this relatively new idea of animal agency and the ethical ramifications of accepting that nonhuman animals too have an interest in shaping their own lives.

Meijer and Bovenkerk identify and review two opposites on a spectrum of approaches to conceptualizing animal agency. The first they call propositional agency, which links agency to capacity for propositional thought. The second they call materialist agency, which links agency to the capacity to move something else. Both views have major problems, either being too limiting and anthropocentric (as human forms of rationality are taken as the standard) or too broad to be of practical use (as a framework to make normative and political judgments is missing). Meijer and Bovenkerk instead propose an alternative working definition of agency, based on a relational approach to ethics that doesn't take an anthropocentric view of agency as a starting point and one that takes the unique perspective of nonhuman animals into account. In their view agency should be seen as the capacity of a subject to influence the world in a way that expresses their desires and will. Their paper highlights the advantages and disadvantages of a relational approach to agency and makes a case for philosophers to engage differently with nonhuman animals in order to develop an interspecies ethics.

Charlotte Blattner's chapter, 'Turning to Animal Agency in the Anthropocene', makes a similar case, but from a judicial perspective. Blattner demonstrates how the current legal system is unable to provide justice for nonhuman animals. While there are laws that claim to protect the welfare of nonhuman animals, Blattner argues these laws in practice serve only to silence nonhuman animals and inhibit their agency by cementing the moral and legal status of nonhuman animals as human property. 
Changes are therefore necessary to make the legal system fair and just towards nonhuman animals. This can only happen once we acknowledge the difficulty of objectively evaluating competing interests of human and nonhuman animals (due to the fact that, as humans we are the ones making the laws while also being the ones who benefit immensely from exploiting nonhuman animals). To overcome this issue, Blattner convincingly argues in favor of honest, unbiased and open-ended research into nonhuman animal agency to empower animal agency and work towards a multispecies polity.

The importance of removing an anthropocentric perspective from the way we think of nonhuman agency is further emphasized in Nathan Kowalsky's chapter, 'Animal Difference in the Age of the Selfsame'. Kowalsky critically reflects on the flaws of the 'growing circle of ethics' perspective, put forward by Peter Singer. He sees an historical development of growing concern from only caring for one's own well-being towards also caring for other humans and eventually caring about nonhuman animals as well. Instead of determining the moral worth of a nonhuman animal by measuring them to the human standard, we should judge them solely on their own merits. By challenging the inherent anthropocentrism in how we decide moral considerability, Kowalsky also touches on a type of nonhuman agency that the previous authors did not discuss in depth, namely moral agency.

\subsection{The Problem of Predation}

Ever since people started making the case for animal rights and questioned the ethics of killing them for food, the question of how to judge predation is one that has been a challenge for philosophers. Especially when one acknowledges the moral agency of nonhuman animals, accepting that their actions might be good or bad, it becomes difficult to ignore the question of whether we have a duty to educate animals in right moral behavior and if we should punish them for behaving in ways we consider deplorable. How should we relate to the state of nature, where life is nasty, brutish and short? Should we try to intervene and police wild animals, e.g. save the gazelle from the hungry lion?

In his chapter, 'Should the Lion Eat Straw Like the Ox? Animal Ethics and the Predation Problem', Jozef Keulartz explores this issue and evaluates the way different philosophers have tried to tackle this problem from different ethical perspectives. He reviews Peter Singer's utilitarian approach, Tom Regan's deontological approach, Nussbaum's capability approach and the political animal rights approach of Donaldson and Kymlicka. Singer argues that the evil of predation cannot be eliminated without introducing worse suffering, while Regan tries to argue it is not our duty to intervene and that nonhumans animals should simply be left alone. Keulartz shows the problem with both approaches and he goes on to discuss Nussbaum's capability approach, which seems promising at first, but ultimately fails to offer a more balanced view of the predator-prey relationship. In the end the political animal rights theory of Donaldson and Kymlicka, which argues that wild animals should be recognized 
as members of separate, sovereign nations, seems the most promising. However, Keulartz identifies problems with their approach as well, arguing that they underestimate the large destruction that is taking place globally, due to climate-change and human activities. Simply giving wild animals back control over their own territories won't save them from the mass extinction that is taking place in the Anthropocene. Keulartz's paper forces us to ask ourselves whether treating wild animal populations as sovereign entities is really the best way to respect nonhuman animal agency.

In the end, it seems that as philosophers we still struggle with how to evaluate the (moral) agency of animals in the context of predator-prey relationship. While it might be clear what the current state of these (often violent) relationships between nonhuman animals is, it is not yet clear what they can and ought to be.

\subsection{Human and Nonhuman Animals}

It's not strange that, as the academic field of animal ethics matures and other interdisciplinary fields like animal studies emerge as well, scientists and philosophers become more sensitive to the ways humans and nonhuman animals are alike. The chapter by Michiel Korthals, 'Humanity in the Living, the Living in Humans', highlights this as it shows how difficult it is to maintain a clear boundary between humans and other animals, based on altruism, language or certain values.

Furthermore, as an academic field we should also become more aware of the interconnectedness and similarity in the ways different groups are oppressed. Only by being mindful of all manners of oppression can an ethical theory be developed that respects the agency of human and nonhuman animals alike. The aim of 'Justified species partiality', the chapter by Ronald Sandler and John Basl, should be seen in this light. While I think that animal ethicists in general might be more aware of and sensitive to the interests of humans with certain impairments or conditions than Sandler and Basl give them credit for, the paper does show how important it is for ethicists to look critically at how their words can be interpreted or (mis)understood. While the famous 'argument from marginal cases' might still be logically valid, no one likes to be called 'marginal', which is another good reason to rename the argument to the 'argument from species overlap', as some philosophers have argued for (Horta 2014).

\subsection{The Future of Agency}

The state of nonhuman animal agency is dire. Human domination unforgivingly curtails opportunities for nonhuman self-realization, the human legal system works against them and mass extinction due to human-caused climate change threatens their continued existence. The discussed authors not only successfully make clear where the theoretical debate on nonhuman animal agency now stands and what the 
remaining conceptual hurdles are, but they also make the societal and moral urgency of more research in this area abundantly clear. As Meijer and Bovenkerk discussed in their paper, philosophers and scientists will need to rethink the way they approach this research, inventing new innovative ways of empirical research that engage with nonhumans animals and gives them the opportunity to reshape our relationship with them and determine their place in our shared society.

\section{References}

DeGrazia, D. 1996. Taking animals seriously: Mental life and moral status. Cambridge: Cambridge University Press.

Donaldson, S., and W. Kymlicka. 2011. Zoopolis: A political theory of animal rights. New York: Oxford University Press.

Gruen, L. 2015. Entangled empathy: An alternative ethic for our relationships with animals. New York: Lantern Books.

Horta, O. 2014. The scope of the argument from species overlap. Journal of Applied Philosophy 31: 142-154. https://doi.org/10.1111/japp.12051.

Monsó, S., J. Benz-Schwarzburg, and A. Huber. 2018. Animal morality: What it means and why it matters. The Journal of Ethics 22 (1): 283-310. https://doi.org/10.1007/s10892-018-9275-3.

Palmer, C. 2001. 'Taming the wild profusion of existing things'? A study of Foucault, power and human/animal relationships. Environmental Ethics 23 (4): 339-358.

Regan, T. 1983. The case for animal rights. Berkley: University of California Press.

Singer, P. 1975. Animal liberation. London: Pimlico.

Joost Leuven studied philosophy and cultural sociology at the University of Amsterdam. He wrote his master theses on the political turn in animal ethics and the 'abolitionist vs welfarist' debate within the contemporary animal rights movement. Between 2014 and 2018 he worked as a dual city councillor for the Party for the Animals in the municipality of The Hague. Currently he works as a high school teacher, teaching philosophy and social science.

Open Access This chapter is licensed under the terms of the Creative Commons Attribution 4.0 International License (http://creativecommons.org/licenses/by/4.0/), which permits use, sharing, adaptation, distribution and reproduction in any medium or format, as long as you give appropriate credit to the original author(s) and the source, provide a link to the Creative Commons license and indicate if changes were made.

The images or other third party material in this chapter are included in the chapter's Creative Commons license, unless indicated otherwise in a credit line to the material. If material is not included in the chapter's Creative Commons license and your intended use is not permitted by statutory regulation or exceeds the permitted use, you will need to obtain permission directly from the copyright holder. 